\title{
CARTAS SOB FOGO CRUZADO: OS JESUÍTAS CONTRA OS HOLANDESES NO BRASIL
}

\author{
Ronaldo Vainfas * \\ Universidade Federal Fluminense- UFF \\ rvainfas@terra.com.br \\ Mário Branco ** \\ Universidade Federal Fluminense - UFF \\ sj1549@ hotmail.com
}

\begin{abstract}
RESUMO: O artigo examina o papel da correspondência na logística da Companhia de Jesus, com ênfase nas cartas emergenciais relacionadas à conquista holandesa no Brasil, no século XVII, muitas vezes redigidas por padres aprisionados ou exilados pelos holandeses. Os autores defendem que, neste gênero epistolar, prevalece o tom de resistência contra o avanço dos "hereges calvinistas" em terra católica, bem como de alerta contra inacianos dissidentes. Neste sentido, destacam-se as cartas do padre Francisco Ferreira sobre o inimigo calvinista e as que monitoravam o padre dissidente Manoel de Moraes. $\mathrm{O}$ artigo sublinha, enfim, a inserção desta correspondência, entre o que se poderia chamar de serviço de inteligência militar da Companhia de Jesus.
\end{abstract}

PALAVRAS CHAVE: Jesuítas - Brasil holandês - Correspondência inaciana - Inteligência militar jesuítica

\section{LETTERS UNDER CROSSFIRE: THE JESUSITS AGAINST THE DUTCH IN BRAZIL}

\begin{abstract}
The article examines the role of correspondence in the logistics of the Company of Jesus, with emphasis on emergency letters related to the Dutch conquest in Brazil in the seventeenth century, often written by priests imprisoned or exiled by the Dutch. The authors sustain that in this epistolary genre the tone of resistance against the advance of "Calvinist heretics" on Catholic soil prevails, as well as alert against dissident Ignatian. In this sense, the letters of Father Francisco Ferreira on the advance of the Calvinists' conquest and those that was monitoring the dissident priest Manoel de Moraes stand out.
\end{abstract}

Doutor em História pela USP, em 1988. Professor Titular aposentado de História Moderna da UFF. Professor Visitante da UERJ entre 2016 e 2017. Atualmente Professor Visitante no Departamento de História da UFRN.

** Doutor em História pela UFF, em 2010. Pesquisador Visitante na UFF com Bolsa da FAPERJ, entre 2010 e 2015. Atualmente Acadêmico Correspondente da Academia Fides et Ratio - Fé e Razão da Arquidiocese de São Sebastião do Rio de Janeiro. 


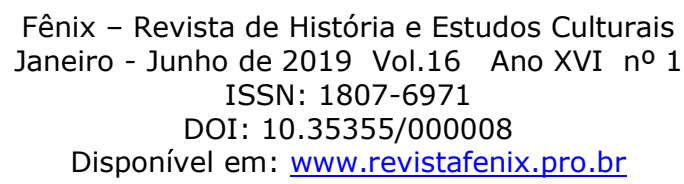

The article underlines, finally, the insertion of this correspondence amidst what could be called the Intelligence Service of the Company of Jesus.

KEYWORDS: Jesuits, Dutch Brazil - Ignatian Correspondence - Jesuit Military Intelligence

\section{A COMPanhia de Jesus no OLHO do FURACÃo}

A Companhia de Jesus se estruturou em meio a um autêntico furacão que, sem nenhuma dúvida, destroçou a unidade da cristandade romana construída na Idade Média. À Igreja de Roma, restava defender a fé católica nas regiões ou monarquias que lhe garantiam fidelidade: os reinos ibéricos, as repúblicas italianas, os territórios da casa de Habsburgo, como a Flandres, a monarquia francesa, cuja fidelidade inquebrantável a Roma fora assinada em 1516, por Francisco I, um ano antes de Lutero afixar suas 95 teses em Wittemberg. Foi neste contexto que Roma reinstalou a Inquisição como tribunal permanente, em 1542, e pouco depois, em 1545, promoveu o Concílio de Trento, que se arrastou até $1563 .{ }^{1}$ Os jesuítas se encaixaram perfeitamente nesta linha de combate, fundando colégios em todas as regiões católicas europeias e organizando missões, desde os anos 1540 nas regiões mais remotas do globo, desde a América portuguesa à Índia, à China, ao Japão.

\section{O PAPEL DA CORRESPONDÊNCIA NA LOGÍSTICA INACIANA}

A estruturação de uma ordem religiosa com tamanha ambição exigia uma logística detalhada, metódica, para o que os jesuítas logo se mostraram preparados, ao seguirem a disciplina deles exigida por Inácio de Loyola e seus discípulos mais grados, como Francisco Xavier. Neste sentido, foi a correspondência sistemática trocada entre a alta direção da Companhia e seus missionários o fator decisivo para o estabelecimento de uma vasta e eficiente rede de informações, cuja abrangência geográfica alcançou todos os quadrantes da expansão jesuítica. A partir de 1556, nas Constituições da Companhia de Jesus foram estabelecidas e normatizadas a frequência da circulação das cartas e a relevância dos assuntos que deveriam ser prioritariamente enviados para a sede dos inacianos em Roma. Esta iniciativa concedeu às cartas jesuíticas o status de

\footnotetext{
1 DELUMEAU, Jean. El catolicismo de Lutero a Voltaire. Barcelona: editorial Labor, 1973.
} 
documentação chave para a compreensão das dinâmicas administrativas e missionárias dos inacianos.

O cuidado com os trâmites da correspondência entre os membros da Companhia era quase uma obsessão de Inácio de Loyola. A sua peculiar meticulosidade inspirou a atenção com que a correspondência foi tratada na formulação das Constituições, de cuja redação o próprio geral se ocupou entre 1541 e 1556. Como se pode perceber, o longo período de elaboração traduz as nuances desse processo. Por fim, após inúmeros contatos entre as diversas casas da Companhia, que levaram em conta as sugestões recebidas de todos os núcleos da expansão jesuítica, chegou-se a versão final, aprovada em 1558, que definiu em dez partes as normas para o "bom governo da Companhia".

As normas que passaram a reger a correspondência dos inacianos foram definidas na oitava parte, exatamente aquela que trata "da união entre os membros da Companhia”. O texto final não deixou de encorajar a tomada das decisões pelos missionários que atuassem na linha de frente do avanço evangelizador. Doravante os Soldados de Cristo deviam conduzir-se de acordo com o que fosse mais apropriado ao momento ou as circunstâncias com as quais se deparassem, visando sempre à Maior Glória de Deus. ${ }^{2}$ Todas as cartas recebidas pelo Geral eram arquivadas em Roma do que resultou na formação de um vasto acervo de cartas e outros documentos reunidos em diversos códices. Posteriormente todos eles foram catalogados pelo nome da província jesuítica responsável pelo envio das cartas à sede romana.

Outro fator merece destaque na correspondência inaciana: a eficiência que seus integrantes demonstraram na coleta e no registro sistemático de informações. Essa característica se tornou dominante desenvolvendo-se ao máximo graças ao conhecimento que os inacianos adquiriram acerca das peculiaridades do cotidiano, da língua, da cultura e costumes das populações nativas, isto é, os habitantes originais das terras onde os religiosos atuaram. Os missionários tornaram-se os agentes e observadores privilegiados da expansão jesuítica cuja atuação, nos séculos seguintes, alcançou uma escala planetária e constituíram-se nos verdadeiros postos de vanguarda do avanço missionário da Igreja católica.

2 Constituições da Companhia de Jesus e normas complementares. São Paulo: Loyola, 1997. p. 211. 
Inúmeros autores têm se ocupado da história da Companhia de Jesus. Dentre eles boa parte ressalta a centralidade da correspondência jesuítica na vida interna e na expansão de suas atividades missionárias. Embora reconheçamos esta característica, evidenciamos para além da função informativa, a formação de um sistema de busca, coleta e difusão de informações, pouco usual naquela época. Na conjuntura de lutas que matizou o Brasil holandês do século XVII, esse sistema tornou-se imprescindível, como veremos adiante, para o enfrentamento de uma situação para a qual os jesuítas não estavam preparados.

O que poderiam fazer aqueles jesuítas? Esta questão foi respondida mediante atividades mais afeitas ao modo de proceder dos religiosos, isto é, através do consolo espiritual e dos cuidados médicos dispensados aos feridos em combate. No entanto, eles fizeram mais, muito mais, tornaram-se os olhos e os ouvidos atentos de seus superiores da Europa e do Brasil. Suas ações podem ser percebidas no texto das cartas que lograram chegar até nossos dias.

\section{OS JESUÍTAS EM FACE DO DOMÍNIO HOLANDÊS NO BRASIL}

Dentre os documentos existentes no Archivum Romanum Societatis Iesu, doravante ARSI, as fontes jesuíticas relativas ao período das lutas contra os invasores holandeses, pertencem os códices Brasilia 5 e Brasilia 8, e reúnem a maior parte da documentação jesuítica produzida pelos missionários que viveram na região nordeste do Brasil durante o século XVII. As cartas escritas pelos jesuítas que viveram e atuaram nas capitanias, sob o domínio das tropas da West-Indische Compagnie doravante WIC, cumpriram um papel muito mais amplo do que simples missivas institucionais. Naquela conjuntura adversa os inacianos fizeram circular notícias pormenorizadas acerca das atividades das tropas e dos agentes da administração holandesa. As cartas tornaram-se elementos primordiais para a montagem de um sistema de informações bastante eficiente, levando-se em conta a precariedade dos meios de comunicação da época. De fato, graças à riqueza de detalhes dos combates que narram, assemelham-se aos relatórios de missão atualmente em uso nos exércitos de todo o mundo, e que são classificadas como 'informações de combate', apreciadíssimas pelos serviços de inteligência militar. 
Algumas cartas jesuíticas daquela época são mais específicas, pois informam além da movimentação de tropas inimigas, os efetivos, os armamentos, quem são os comandantes inimigos e chegam a indicar as intenções e probabilidade de eventuais operações inimigas. Estas cartas podem ser classificadas no âmbito das 'informações estratégicas'. Nesse aspecto, em particular, os jesuítas se superaram. Basta lembrar que pelo menos em duas ocasiões conhecidas, cartas que veicularam notícias de cunho estratégico foram enviadas dos cárceres holandeses. Esse foi o caso das cartas escritas pelos padres Domingos Coelho (1564-1639), em 24 de outubro de 1624 e Francisco Fernandes (1583-1639), datada de 26 de setembro de 1636.

O sistema de informações jesuítico foi levado ao limite durante a conjuntura de enfrentamento armado contra os holandeses no Brasil, não só em 1624, na Bahia, e também, a partir de 1630, na capitania de Pernambuco e demais regiões produtoras de açúcar do nordeste brasileiro. Não resta dúvida que durante a guerra de conquista empregada pelas tropas e navios das Províncias Unidas, as cartas jesuíticas tiveram de cumprir um papel muito mais amplo do que se poderia esperar de uma simples comunicação institucional interna. Na verdade os missionários constituíram-se nos elementos primordiais para a montagem e operação de um eficiente serviço de inteligência, que atuou infiltrado nas áreas dominadas pelos invasores calvinistas e contribuíram decisivamente para a expulsão dos holandeses em 1654.

Do mesmo modo que ocorreu com as cartas dos jesuítas que missionaram no Brasil do século XVI, boa parte da correspondência jesuítica escrita entre 1600 e 1630, foi publicada graças ao profícuo trabalho do insigne historiador jesuíta, o padre doutor Serafim Leite (1890-1969). ${ }^{3}$ A análise destas cartas permite perceber, numa chave de leitura religiosa, o testemunho vivo dos missionários diante das vicissitudes que enfrentaram De fato, realçaram o favor divino concedido aos Companheiros de Jesus e seus aliados, nas lutas contra as hostes dos invasores calvinistas.

Desde 1624, e principalmente a partir de 1630, os missionários da Companhia de Jesus apoiaram incondicionalmente as forças coloniais que se defrontaram com os holandeses. Os jesuítas participaram de todas as fases da 'guerra de Pernambuco', como

3 LEITE, Serafim. História da Companhia de Jesus no Brasil, Assistência de Portugal, 1549-1760. Lisboa: Portugália; Rio de Janeiro: Civilização Brasileira, 1938-1950.(10volumes.). 
então se dizia, e da resistência contra as tropas enviadas aos trópicos pelos dirigentes das Províncias Unidas.

Apesar de todas as atividades realizadas pelos inacianos durante as lutas contra a dominação holandesa, inúmeros cronistas das guerras de Pernambuco pouco, ou quase nada, relataram sobre as ações dos religiosos da Companhia de Jesus durante aquele longo conflito. As poucas referências que eventualmente surgem, aqui e ali, nos textos produzidos naquela época, se referem apenas às ações dos jesuítas ligadas mais diretamente aos encargos dos religiosos, tais como confissões, missas e procissões. Desde então permaneceu o silêncio e a omissão acerca das ações que foram inspiradas, conduzidas ou realizadas pelos Soldados de Cristo.

No entanto, ainda que se possa escrever a história daquelas guerras sem fazer qualquer menção à participação dos inacianos, a narrativa estará irremediavelmente comprometida e incompleta. A omissão da participação jesuítica nas lutas contra os holandeses dificulta e empobrece o entendimento e a análise dos pormenores acerca dos acontecimentos cruciais daquela conjuntura. Afinal, se por um lado, é necessário reconhecer que os cronistas daqueles episódios certamente tiveram que enfrentar inúmeras limitações de acesso às informações, por outro lado, não menos importante, também é correto afirmar que alguns deles tiveram suas motivações pessoais para exaltar os feitos de uns e calar as realizações de outros.

Todavia, desarmados os espíritos, não se pode menosprezar a contribuição ao trabalho dos historiadores a partir dos relatos escritos pelos cronistas e pelos religiosos. De fato, foi a partir das informações contidas em suas obras, muitas delas escritas no calor dos acontecimentos narrados, que se tornou possível aos historiadores desenvolverem suas análises, permitindo-lhes entender, explicar, e resgatar, na medida do possível, as nuances daquela realidade distante.

Numa abordagem mais propriamente histórica, também é possível notar que as cartas escritas pelos padres da Companhia de Jesus são documentos preciosos sobre o cotidiano daquela época conflituosa. Assim, graças à riqueza de detalhes divulgados pelos missionários em suas cartas, é possível ao leitor atento, vislumbrar para além do pano de fundo do cenário colonial, o ambiente de incertezas, dificuldades e perigos que matizou as atividades dos jesuítas e de todos que combateram contra as tropas holandesas. 
Um episódio dessa época conflituosa ilustra a percepção desenvolvida pelos comandantes militares das Províncias Unidas acerca dos danos que lhes seriam causados pelos jesuítas e suas cartas. Em fins de maio de 1624, o padre Domingos Coelho, provincial da Companhia de Jesus no Brasil, em seus últimos dias de mandato, voltava à capital colonial acompanhado de outros religiosos. Naquela ocasião o provincial encerrava uma viagem oficial às sedes dos jesuítas situadas nas capitanias ao sul da colônia. A fragata na qual viajava já se encontrava no litoral da Bahia, quando foi capturada por uma nau holandesa da esquadra atacante, cujas tropas, poucos dias antes, haviam ocupado a cidade de Salvador.

Durante o tempo em que ficou recolhido ao porão de uma das embarcações holandesas, o Provincial dos jesuítas foi mantido sob a mais estrita e severa vigilância. Submetido a vários interrogatórios o padre Domingos Coelho dirigiu-se a um de seus captores e perguntou-lhe a razão para a prisão dos jesuítas. O holandês retrucou prontamente, 'vocês sabem demais, vocês escrevem demais'.

Do mesmo modo, já durante a ocupação da capitania de Pernambuco, entre 1630 a 1654, os invasores reconheceram o perigo que os missionários da Companhia de Jesus, e as notícias que faziam circular através de suas cartas, representavam para a sobrevivência do Brasil holandês. De fato, 'o perigo dos eclesiásticos' sempre assombrou o sono dos dirigentes holandeses. Os jesuítas eram acusados, com razão deve-se dizer, de serem os mais perigosos inimigos do Brasil holandês.

A correspondência jesuítica entre 1630 e 1640 é uma fonte primordial para o entendimento da conjuntura da guerra de resistência aos soldados da WIC, bem como os seus reflexos na vida interna da ordem inaciana. Vários jesuítas desempenharam funções de relevância naquela guerra. As cartas destes missionários podem ser classificadas levando-se em conta duas tipologias: por um lado, as que foram escritas pelos religiosos cujas ações estiveram inseridas nos quadros estratégicos mais amplos da luta contra os holandeses. Por outro, as cartas que além de informarem os dirigentes da Companhia de Jesus no Brasil e na Europa, contribuíram para orientar o processo decisório dos conselhos régios da Espanha e, depois de 1 de dezembro de 1640, o rei D. João IV de Portugal.

Os jesuítas sempre estiveram na vanguarda, ora animando os soldados da resistência através da assistência religiosa aos combatentes; ora liderando grupos de 
índios flecheiros que viviam nos aldeamentos jesuíticos. Os flecheiros, graças ao destemor com que combatiam, tornaram-se indispensáveis nos combates contra os soldados da WIC. Destacaram-se nestas ações o padre Manuel de Moraes e seus flecheiros da aldeia de São Miguel do Muçuí, em Pernambuco e no Maranhão na década de 1640, o padre Lopo do Couto.

Aliás, o episódio da captura do padre provincial Domingos Coelho e dos demais religiosos que o acompanhavam, serve para ilustrar o modus operandi adotado pelos holandeses no trato com os jesuítas que conseguiram capturar. Por conseguinte, as forças de ocupação da WIC sempre se mantiveram alertas contra a circulação das cartas daqueles padres que 'escreviam demais'.

A carta anua de 1631 possui especial importância para que se possa avaliar a extensão dos danos, em 'sangue vidas e fazenda', causados aos jesuítas pelos invasores holandeses. Nessa carta foram relatadas as ações dos religiosos da Companhia de Jesus, do Colégio de Olinda e missionavam nas aldeias estabelecidas pelos jesuítas em Pernambuco, quando do ataque dos soldados da WIC no ano anterior. Do mesmo modo indica com exatidão, quantos e quais eram os padres e irmãos coadjutores que se defrontaram com as tropas holandesas, permitindo avaliar a extensão das ações de guerrilha realizadas pela resistência pernambucana, na qual os jesuítas participaram desde os primeiros momentos da luta. Não deixa de causar espanto o fato de que durante todo aquele período o efetivo de missionários jamais passou de trinta e cinco jesuítas que enfrentaram, no auge da luta pela capitania de Pernambuco e arredores milhares de soldados das tropas de ocupação mantidas naquela região pela WIC.

Existe outra carta jesuítica que também é digna de nota. Referimo-nos àquela que foi enviada ao Padre Geral Múcio Vitelleschi, pelo provincial dos jesuítas no Brasil, o padre Domingos Coelho, em 24 de outubro de 1624. Como se viu anteriormente, o Provincial do Brasil foi capturado em fins de maio daquele ano e permaneceu confinado a bordo de um dos navios da esquadra holandesa por mais dois meses. Somente em julho ele e seus companheiros de cativeiro foram extraditados para a Holanda. Logo após a chegada o grupo de prisioneiros jesuítas foi dividido, parte seguiu para Dordrecht, outros, dentre eles o provincial, foi recolhido ao cárcere em Amsterdã.

Cabe destacar que graças ao trabalho de Serafim Leite, incansável historiador da Companhia de Jesus, o texto original desta carta do Provincial do Brasil foi 
localizado no acervo do Archivum Romanum Societatis Iesu, em fins da década de 1930. Até então, este documento permanecera inédito e somente foi publicado na íntegra, em 1945, no quinto volume da História da Companhia de Jesus no Brasil. ${ }^{4}$

Dentre as particularidades desta longa carta, cabe destacar que ela foi escrita durante os dois meses de confinamento que o padre Domingos Coelho sofreu a bordo de um navio holandês, ancorado na Baía de Todos os Santos. Posteriormente, o jesuíta acrescentou o relato das peripécias que enfrentou, junto com seus companheiros de infortúnio durante a viagem entre o Brasil e a Holanda. A narrativa segue a ordem cronológica dos acontecimentos, a partir da captura da fragata da Companhia de Jesus no litoral da Bahia.

Curiosamente, apesar de se encontrar confinado no navio do capitão Piet Heyn, o padre Domingos Coelho conseguiu colher notícias fidedignas sobre o que havia acontecido em Salvador. Segundo suas próprias palavras, essas informações foram obtidas, 'depois de me informar muito devagar assim dos mesmos holandeses como de portugueses de muito crédito que se acharam presentes'. De certo, seus primeiros informantes foram alguns dos boquirrotos marujos holandeses. Em sua carta o jesuíta expôs além dos pormenores do ataque holandês, a rapidez com que a cidade de Salvador foi abandonada pelas tropas coloniais.

Domingos Coelho também teceu amplos comentários sobre as providências tomadas pelos holandeses no sentido de cooptar o apoio da população de Salvador, permitindo aos beneditinos, franciscanos e carmelitas que retornassem à cidade e aos seus mosteiros. Do mesmo modo, os comandantes das tropas de ocupação concederam que os ofícios religiosos dos católicos fossem celebrados, desde que as missas e demais cerimônias fossem celebradas com as portas das igrejas fechadas. No entanto, com indisfarçável orgulho, o Provincial dos jesuítas relatou que únicos excluídos das benesses oferecidas pelos invasores aos religiosos foram os padres da Companhia de Jesus. Todavia, para regozijo do provincial dos inacianos, nenhum dos padres das outras ordens aceitou as condições impostas pelos holandeses.

O padre Domingos Coelho, descreveu o saque que a cidade de Salvador sofreu pelas mãos dos soldados da WIC, ressaltando a destruição que se abateu sobre as

4 LEITE, Serafim. História da Companhia de Jesus no Brasil, Assistência de Portugal, 1549-1760. Lisboa: Portugália; Rio de Janeiro: Civilização Brasileira, 1938-1950.(10volumes.). 
igrejas, os mosteiros e o próprio Colégio da Companhia de Jesus. Essas ações foram creditadas pelo jesuíta ao intenso ódio que os calvinistas holandeses manifestavam contra a Igreja de Roma. No entanto, embora todos os templos católicos tenham sido saqueados, e suas imagens sacras destruídas, numa clara manifestação de odio fidei, cabe lembrar que, para os padrões da época, o saque das praças conquistadas era o modus operandi adotado pelas tropas qualquer que fosse a crença religiosa de seus soldados.

A razão para a inegável perseguição movida pelas tropas da WIC aos religiosos da Companhia de Jesus tinha raízes mais profundas e foi claramente exposta nesta carta. O Provincial relatou que conversou com inúmeros holandeses durante o tempo em que permaneceu aprisionado no litoral baiano. No entanto, um deles, que se apresentou como mercador em Amsterdã, acusou os religiosos da Companhia de Jesus de se envolverem em assuntos da alçada dos governantes, pois, segundo disse ao padre Domingos Coelho, os jesuítas incentivavam e convenciam os príncipes cristãos a perseguirem e fazerem guerra contra os calvinistas. Como era de se esperar, o superior dos inacianos negou que assim fosse alegando que as Constituições da Companhia de Jesus os proibiam de participar dessas atividades.

É óbvio que o mercador de Amsterdã não se deixou levar pelos argumentos do Provincial do Brasil. Afinal, historicamente as imputações que fizera aos jesuítas tinham sua razão de ser. De fato, desde o século anterior os religiosos da Companhia de Jesus destacaram-se pela defesa da ortodoxia católica, frente aos postulados reformistas de Lutero e Calvino. O mesmo se pode dizer quanto à inegável influência que seus confessores exerciam sobre as consciências dos membros das casas reais da Europa.

Ainda que o Provincial tenha assegurado que esses assuntos foram abordados em 'conversas que teve com o comerciante de Amsterdã', cujo nome não declinou, na verdade tratava-se de um interrogatório. Muito embora tenha sido conduzido em latim, e sem o emprego de violência física, o padre Domingos Coelho sabia dos riscos que corria. Portanto, como chefe dos jesuítas do Brasil, ele jamais poderia admitir a veracidade de tais acusações. ${ }^{5}$

Prosseguindo em sua narrativa, o jesuíta deu conta ao Geral da Companhia, sobre os detalhes da extradição dos religiosos capturados na Bahia. O grupo foi

\footnotetext{
5 Archivum Romanum Societatis Iesu. Códice Brasiliae 8, f. 352-355.
} 
confinado por quase dois meses nos porões dos barcos holandeses e, somente no dia 25 de julho de 1624, deixou a Baía de Todos os Santos com destino às Províncias Unidas, onde finalmente desembarcou em outubro daquele ano. ${ }^{6}$

Apesar das dificuldades enfrentadas por seus integrantes naquela ocasião, a rede de informações estabelecida pela Companhia de Jesus na Europa, mostrou sinais claros e inequívocos de sua eficiência e abrangência. Afinal foi possível ao Provincial do Brasil romper o isolamento do cárcere em Amsterdã, e enviar sua carta ao Padre Geral Mucio Vitelleschi, que se encontrava na sede dos inacianos em Roma. É certo que essa carta foi contrabandeada para fora das fronteiras das Províncias Unidas, ainda nos primeiros dias subsequentes à chegada dos jesuítas prisioneiros em Amsterdã. Como se sabe, a Igreja de Roma, através da Missio Hollandica, mantinha um grupo de religiosos que atuavam secretamente naquela região, levando o conforto espiritual e ministrando os sacramentos à população católica dos Países Baixos.

É possível que a carta do padre Domingos Coelho tenha conseguido chegar a Roma por outros caminhos menos conhecidos graças aos inúmeros agentes comerciais, muitos deles criptocatólicos que atuavam livremente nas Províncias Unidas. Afinal, em razão de suas atividades profissionais, esses homens faziam parte de uma rede de correspondentes cuja abrangência se estendia a todos os portos da Europa. De todo modo, é bastante provável que um deles, certamente simpatizante dos Companheiros de Jesus, possa ter sido cooptado para essa arriscada empreitada. No entanto, não se pode descartar a possibilidade de que esta carta do Provincial do Brasil tenha sido levada para fora dos muros do cárcere em Amsterdã, mediante o suborno de marinheiros ou, quem sabe, de algum dos seus carcereiros.

Seja como for, para verificar a validade dessa hipótese, foi necessário avançar um pouco mais o limite cronológico proposto para este artigo. Assim, conseguimos encontrar uma carta do padre jesuíta holandês Jacobo Roland, enviada da Bahia, em 21 de maio de 1673, ao seu compatriota, o padre Filipe Vanderstraeten, que naquela ocasião se encontrava em missão na cidade de Amsterdã. Entre outros assuntos, o padre Roland citou nominalmente um agente comercial holandês, 'o senhor Simão Granaet, que Deus guarde por muitos anos,' que de sua casa em Lisboa, se encarregava de reenviar para as cidades de Roma e de Salvador, as cartas dos jesuítas, particularmente

\footnotetext{
6 Archivum Romanum Societatis Iesu. Códice Brasiliae 8, f.355.
} 
daqueles que se encontravam atuando em Flandres. Do mesmo modo, a rede dos mercadores europeus, através da qual circulava a sua correspondência, certamente estava intacta e apta a fazer com que o Geral da Companhia de Jesus se tornasse um dos primeiros dirigentes da Europa a receber as informações sobre a ousada ação militar realizada nos trópicos pelas tropas e navios da WIC conforme informou a carta do Provincial Domingos Coelho.

\section{A TRAIÇÃo DE UM JESUÍTA PROMISSOR: O PADRE MANUEL DE MORAES}

O empenho dos jesuítas em combater o "herege flamengo" no Brasil ou onde fosse, mesmo que exilados, foi arranhado pela trajetória de um inaciano vacilante. Para os estudiosos do Brasil holandês, um homem célebre, padre Manoel de Moraes, referido linhas atrás. Natural de São Paulo, nascido em 1596, mestiço de portugueses e índios, desde criança se apegou aos padres do Colégio erguido em Piratininga, embora os irmãos fossem todos "bandeirantes", caçadores de índios para vender nas lavouras coloniais. $^{7}$

Foi remetido para o Colégio da Bahia, onde seguiu os ensinamentos da Ratio Studiorum, aprendeu latim, familiarizou-se com a Escolástica e outros saberes ministrados no curriculum inaciano. Foi aluno destacado, inclusive porque, como paulista, conhecia a língua geral do berço (ou da rede) e não da gramática anchietana. $\mathrm{O}$ provincial Domingos Coelho percebeu muito cedo o potencial de Manoel de Moraes e o enviou como missionário para Pernambuco, em 1623.

Padre Manoel atuou na catequese de modo exemplar, conseguindo ajuntar tabajaras e potiguaras no aldeamento de São Miguel de Muçuí. Foi mentor de um guerreiro que, no futuro, seria o líder dos potiguaras aliados aos luso-brasileiros nas guerras pernambucanas: Antônio Filipe Camarão, ninguém menos.

Quando os holandeses atacaram Pernambuco, em 1630, Manoel de Moraes, como todos os jesuítas ali atuantes, foram mobilizados pelo governador Matias de Albuquerque para organizar os índios aldeados de modo a engrossar as tropas de resistência. Padre Manoel fê-lo com denodo, mais foi além. Pegou em armas, tornou-se “capitão de emboscada". Mostrou-se tão destro no comando dos índios a ponto de irritar

7 VAINFAS, Ronaldo. Traição - um jesuíta a serviço do Brasil holandês processado pela Inquisição. São Paulo: Companhia das Letras, 2008. 
capitães portugueses invejosos, bem como companheiros inacianos indignados com a conduta excessivamente secular de padre Manoel.

Há farta documentação sobre a atuação de Manoel de Moraes na resistência pernambucana, na qual chegou a exercer o posto de "Capitão do gentio no Arraial do Bom Jesus”. Assim como também há fontes variadas - portuguesas e flamengas - sobre a sua rendição na Paraíba, em 1634. Padre Manoel não apenas se rendeu como aderiu aos holandeses, como um novo Calabar. Secularizou-se, passou a vestir-se como militar da WIC, ambicionou liderar tropas neerlandesas na conquista do nordeste açucareiro. Para os holandeses, ter um jesuíta entre os seus era um triunfo inaudito.

Um só documento sobre o engajamento de Manoel de Morais na guerra encontramos na carta do rei Filipe IV de Espanha ao Provincial da Companhia em Portugal, Diogo Monteiro, datada de 31 de outubro de 1631. Ordenava que este fizesse transmitir ao Provincial do Brasil, a sua aprovação aos "procedimentos de Manoel de Moraes, pelo zelo com que os índios o seguiam”, e mandando que o agradecessem, em seu real nome, pelos feitos que vinha obrando na guerra. ${ }^{8}$ Outro exemplo, agora da passagem do jesuíta para o lado flamengo, vemo-lo em Johanes de Laet, um dos diretores da WIC que, na sua História ou Anais dos feitos da Companhia das Índias Ocidentais, não hesitou em dizer que o "Padre Manoel de Moraes exercia a maior autoridade sobre todos os selvagens daquela região e passou voluntariamente para os nossos." 9

O fato é que, desde que lutou na resistência contra os holandeses, Padre Manoel despertou alguma indignação, para dizer o mínimo, nos colegas da Companhia de Jesus. Várias testemunhas da época, depondo no processo que o Santo Ofício haveria de mover contra o padre, deram conta desta insatisfação, a exemplo de Domingos Velho, segundo o qual "os religiosos da Companhia andaram desgostosos com Manoel e trataram de o tirar do Arraial" e, "do dito ofício que aí tinha de capitão do gentio, dizendo que não era decente que um religioso fizesse aquele ofício". ${ }^{10}$ Duarte de Albuquerque Coelho confirma a repercussão da conduta de Manoel, em suas Memórias

8 LEITE, Serafim. História da Companhia de Jesus no Brasil, Assistência de Portugal, 1549-1760. Lisboa: Portugália; Rio de Janeiro: Civilização Brasileira, 1938-1950. . p. 364 (tomo V, 1945).

9 LAET, Joannes de. História ou Anais dos feitos da Companhia das Índias Ocidentais, desde o começo até o fim do ano de 1636. CD-ROM, São Paulo: Editora. Beca, 2003.

10 Instituto Arquivo Nacional da Torre do Tombo. Inquisição de Lisboa. Processo 4847, fólios 22-23 
Diárias, informando que vários inacianos repreenderam o padre, sem que ele os ouvisse, de modo que se afastaram e o deixaram isolado. Seu modo de proceder, conclui o cronista, "não era aquele, com tanta excelência, próprio dos padres jesuítas". Manoel de Moraes acabou perdendo o posto para o seu adjunto, Filipe Camarão. ${ }^{11}$

Seja como for, o que mais importa, para os objetivos deste artigo, é sublinhar o monitoramento exercido pela Companhia de Jesus da conduta de Manoel de Moraes desde o seu engajamento como "capitão do gentio" até a sua passagem para os flamengos. Novamente aqui, as cartas arquivadas no arquivo jesuítico do Vaticano comprovam a importância da correspondência inaciana como fonte histórica e evidência de sua estratégia governativa. No tempo em que lutava contra os holandeses, Manoel de Moraes atropelou sem delongas o voto de castidade, deitando-se com variegadas índias. É o que encontramos em carta de ninguém menos do que o Provincial Domingos Coelho escrita ao Padre Viteleschi, em 28 de agosto de 1635, na qual informou ter ordenado o desligamento de Manoel desde antes "deste cair prisioneiro dos holandeses", pela "má fama que dele corria em matéria de sexto". ${ }^{12}$ Os jesuítas não dispensavam qualquer detalhe, mesmo os mais íntimos. Referia-se o Provincial, nesta carta, ao sexto mandamento (não fornicarás), o que hoje pode parecer algum código secreto, mas entre os inacianos era linguagem corrente. Quando muito, um código deles - e de outros religiosos também - que os historiadores dedicados a tais estudos conhecem bem.

Além de lastimar o dano que causava à imagem da Companhia de Jesus, a traição de Manoel era uma decepção pessoal para padre Domingos Coelho. Conhecera Manoel de perto, no seu primeiro provincialato (1621-1628), quando este ainda era estudante no Colégio da Bahia. Admirou tanto as suas qualidades que o levou consigo para Pernambuco, confiando-lhe o governo da aldeia de São Miguel, em 1623, antes mesmo de Manoel fazer o quarto voto da Companhia de Jesus. A decepção do provincial era tamanha que não se cansava de falar no assunto, irritado, segundo contou ao Santo Ofício padre Rafael Cardoso, também jesuíta, denunciando Manoel.

Apesar de tudo, os inacianos se empenharam em demover Manoel de Moraes da decisão de juntar-se aos flamengos, trocando a Companhia de Jesus pela Companhia

11 COELHO, Duarte de Albuquerque. Memórias Diárias da Guerra do Brasil. CD-ROM, São Paulo: Editora Beca, 2003. pp. 42-50.

12 Archivum Romanum Societatis Iesu. Códice Brasiliae 8, fólios 476-476v. 
das Índias, a fé católica pelo calvinismo, a Igreja de Roma pelo dinheiro holandês. Até o último minuto tentaram os jesuítas convencer Manoel a deixar os holandeses, como relatou Francisco Ferreira, ex-reitor do colégio pernambucano, escrevendo ao Padre Geral Vitelleschi, em 1635. Informou que havia enviado três cartas a Manoel, pedindolhe que voltasse para o lado português. Todas ficaram sem resposta. ${ }^{13}$

Manoel de Moraes acabou enviado à Holanda pelos novos senhores, em 1635, incumbido de dar consultoria à WIC em assuntos brasílicos. Viveu oito anos na Holanda, prestando vários serviços, entre os quais um vasto relatório sobre quantas aldeias havia no território flamengo-brasílico, a população de cada uma, a localização exata, o número de guerreiros, o nome dos chefes em português e na língua geral. ${ }^{14}$ Outra contribuição valiosa do jesuíta renegado à WIC foi a proposta que ofereceu aos Herren XIX para a missionação calvinista das aldeias até então controladas pelos jesuítas. Padre Manoel, então convertido ao calvinismo, ambicionou liderar esta empresa, mas não prosperou. Mas seu plano, contudo, foi adotado. ${ }^{15}$

Padre Manoel não respondeu às cartas dos companheiros. Aceitou com indiferença a sua expulsão da Companhia de Jesus. Chegou a contrair não um, mas dois matrimônios em terras batavas. Teve filhos e filhas. - Jesuíta renegado. Desistiu, ao menos no foro exterior, de ser inaciano. Causou imenso problema para a Companhia de Jesus, quer no Brasil, quer em Portugal. ${ }^{16}$ Quando Manoel de Moraes foi processado pela primeira vez - à revelia, pois estava na Holanda, citado como "religioso da companhia de Jesus" o Provincial em Portugal, padre Simão Dias, logo escreveu à Inquisição, relatando que Manoel de Moraes havia sido "despedido" da Companhia antes que se passasse aos holandeses e "muito antes" que aderisse ao calvinismo, acrescentando que ele só havia professado os votos simples dos jesuítas, concluídos os dois anos de noviciado, mas não os votos solenes. Considerou o provincial que, por ter sido expulso, estava desobrigado dos votos de religião e não se poderia chamá-lo de

13 Archivum Romanum Societatis Iesu. Códice Brasiliae 8, fólios.481-481v.

14 LAET, Joannes de. História ou Anais dos feitos da Companhia das Índias Ocidentais, desde o começo até o fím do ano de 1636. CD-ROM, São Paulo: Editora. Beca, 2003.

15 Nationaal Archief - Haia. Códice 1.01.01, inventarius 8, microfilme 46.

16 Para a repercussão da defecção de Manoel de Moraes na rebelião antijesuítica no Rio de Janeiro, ver LEITE, Serafim. História da Companhia de Jesus no Brasil, Assistência de Portugal, 1549-1760. Lisboa: Portugália; Rio de Janeiro: Civilização Brasileira, 1938-1950. pp. 581-582. Apêndice C. Tomo VI [1945]. No caso da rebelião contra os jesuítas em São Paulo, ver: BOXER, Charles. Os holandeses no Brasil. São Paulo: Companhia Editora Nacional, 1961. p.381. 
religioso. Sua preocupação era óbvia e explícita: “o descrédito da Companhia (de Jesus) e seus religiosos" por causa da divulgação de tais editais. De modo que para evitar “infâmias como as que a Companhia tem experimentado em outras ocasiões", solicitou o provincial que, nos editais seguintes, bem como na sentença contra Manoel de Moraes, fosse suprimida qualquer alusão à Companhia de Jesus. ${ }^{17}$

Um dissidente assumido. Com o passar dos anos, no entanto, revelou-se mais católico do que imaginava ser no foro íntimo. Mais jesuíta do que nunca. Arrependeu-se muito antes de ser preso pelo Santo Ofício, em 1645. Mas se arrependeu tarde. Os inacianos jamais o receberiam de volta.

\section{DILEMA INACIANO EM FACE DO HOLANDÊS: O PAPEL DO PADRE FRANCISCO FERREIRA}

O caso de Manoel de Moraes é um exemplo-limite dos dilemas que assolaram a Companhia de Jesus no Brasil conquistado pelos holandeses. Exceção, não regra. Os dilemas da Companhia foram mais gerais, institucionais, especialmente ligados à questão de como manter o seu legado, o sistema educacional, a catequese, a missionação quase centenária, enfim, face ao avanço de um inimigo protestante.

Um episódio ocorrido em meados de 1635 corrobora o alcance da correspondência jesuítica e a eficiência do seu sistema de informações em momento crítico. Naquela ocasião ocorreu uma virtual cisão entre os jesuítas, cujas origens e consequências passaram despercebidas aos holandeses e não foi sequer registrada pelos cronistas luso-brasileiros da guerra de Pernambuco. Tudo começou a partir da queda do Arraial do Bom Jesus, em junho daquele ano. Naquela ocasião surgiu um desentendimento entre os missionários mais antigos, muitos dos quais veteranos na guerra contra os soldados da WIC e o recém-nomeado Vice-Reitor do Colégio de Olinda, o padre Francisco Ferreira.

Todavia, diante da situação vivida em Pernambuco, tratava-se de uma filigrana administrativa tipicamente jesuítica. Na realidade o padre Ferreira tornara-se dirigente de um colégio que deixara de existir. A vila de Olinda, onde se localizava a sede do colégio dos jesuítas, havia sido ocupada pelos holandeses desde os primeiros dias do

17 Instituto Arquivo Nacional da Torre do Tombo. Inquisição de Lisboa. Processo 4847, fólios 47-50. 
ataque de 1630. Posteriormente, o comandante das tropas da WIC, alegando a impossibilidade de defendê-la convenientemente das surtidas dos guerrilheiros do Arraial do Bom Jesus, decidiu incendiá-la e Olinda foi reduzida a cinzas e escombros.

Após sua chegada a Pernambuco no dia 21 de fevereiro de 1635, pouco depois da tomada da capitania da Paraíba pelos holandeses, o padre Francisco Ferreira resolveu instalar-se na aldeia de Pojuca. Poucos meses se passaram até que se tornou iminente a queda do Arraial do Bom Jesus, sabendo do destino que era reservado pelas tropas da WIC aos jesuítas que lhes caíam nas mãos, o Provincial da Companhia de Jesus no Brasil, padre Domingos Coelho, o mesmo que havia sido capturado pelos holandeses em 1624, exercendo, então, o seu segundo mandato, determinou, através de uma carta enviada em princípios de janeiro de 1635, que, caso se confirmasse a derrocada do 'Real do Bom Jesus', todos os missionários deveriam buscar refúgio na Bahia. O provincial recomendou aos religiosos que conduzissem para o território baiano todos os índios das aldeias jesuíticas situadas na capitania de Pernambuco. O mesmo cuidado já havia sido tomado pelos religiosos das aldeias situadas na Paraíba quando da controversa rendição daquela capitania aos holandeses.

O padre Francisco Ferreira defendia outro ponto de vista, pois, caso a saída dos religiosos se concretizasse, os moradores da capitania ficariam sem os sacramentos e o consolo espiritual proporcionado pelos padres da Companhia de Jesus. Por conseguinte, Ferreira solicitou permissão para permanecer na capitania com alguns jesuítas que esposavam a mesma opinião.

$\mathrm{Na}$ sede dos inacianos em Salvador, o provincial Domingos Coelho, esforçouse para fazer com que o padre Ferreira mudasse de ideia. O Provincial argumentava com pleno conhecimento de causa, afinal entre 1624 e 1627 conhecera de perto a 'hospitalidade' reservada pelos calvinistas das Províncias Unidas aos religiosos da Companhia de Jesus. Apesar de tudo, o padre Ferreira mostrou-se irredutível, e a crise instalou-se definitivamente.

O imbroglio institucional foi resolvido através do modus faciendi dos inacianos previsto nas Constituições. Diante das alegações do padre Ferreira, o provincial Domingos Coelho, deixou a cargo da consciência de cada religioso a decisão sobre a permanência na capitania. Portanto, o vice-reitor do inexistente colégio de Olinda, preferiu ficar onde estava e aguardar a chegada das tropas holandesas. Basta observar 
com cuidado de onde partiu a última carta que o recalcitrante missionário enviou ao Geral dos jesuítas, Múcio Vitelleschi, para perceber que algo saíra errado. De fato, confirmando os receios do provincial do Brasil, a carta do padre Francisco Ferreira foi remetida no dia 26 de setembro de 1636, da cidade de Antuérpia!

No longo texto que escreveu o jesuíta narrou os pormenores de sua prisão. Contudo, enquanto esteve recolhido nos cárceres de Recife e antes de ser finalmente deportado para as Províncias Unidas, tratou de anotar detalhes preciosos acerca do que conseguira observar sobre o efetivo e a movimentação das tropas da WIC. Do mesmo modo, pelo que se pode perceber pelas minúcias que relatou o padre Ferreira também conseguiu colher algumas notícias durante seu tempo de prisão nos cárceres holandeses em Amsterdã. "Pernambuco está acabado. Têm os Holandeses mais de seis mil homens de guerra e agora vai Maurício Conde, [Nassau] com três mil homens com intento de, com os que estão em Pernambuco, ir à Baía [...]. Isto reverendo padre são os pecados do Brasil". ${ }^{18}$

Dentre todas as notícias que constam desta carta, existe uma que surpreende por sua relevância. Desde meados de 1636 circulavam fortes rumores nas Províncias Unidas, percebidos e relatados pelo padre Francisco Ferreira, sobre a iminente partida da frota que conduziria até Pernambuco o recém-nomeado Governador e Comandante em Chefe das tropas holandesas nos trópicos, o nobre alemão Maurício de Nassau. Como se sabe, ele iniciou sua viagem no mês de outubro daquele ano, chegando ao Brasil em janeiro de 1637.

A carta do padre Ferreira tornou-se um dos primeiros documentos através do qual os jesuítas fizeram com que a notícia de um novo ataque holandês à Bahia, viesse a circular para além das fronteiras das Províncias Unidas. Mas o padre Francisco Ferreira foi muito mais meticuloso em seu relato, ao indicar o objetivo primordial da missão confiada a Maurício de Nassau: atacar a capital colonial do Brasil. De fato, é nesta carta que surge claramente a primeira noticia acerca das intenções estratégicas dos dirigentes da WIC, a partir da nomeação de Nassau para governar o Brasil holandês. Do mesmo modo, é possível perceber que além da eficiência dos meios de coleta de informações da Companhia de Jesus, a existência de um sistema de transmissão destas notícias que se

18 Archivum Romanum Societatis Iesu. Códice Lusitania 74, fólio. 270. 
encarregava de fazer com que elas chegassem ao seu destino final, isto é, à sede dos jesuítas em Roma.

Portanto, não foi por acaso que o padre Ferreira esperou até que conseguisse chegar à cidade de Antuérpia para enviar as informações que colhera durante a sua estadia nos cárceres de Recife e nas Províncias Unidas. Além de 'terra católica', aquela cidade contava com um serviço de correios cuja eficiência tornara-se uma referência na Europa, desde a segunda metade do século XVI. Seguindo a rota então existente, a carta do jesuíta chegou inicialmente a Lisboa, sede da Província Portuguesa da Companhia de Jesus, dali foi reenviada para o Padre Geral em Roma.

De todo modo, o códice no qual foi inserida, e onde se encontra até os nossos dias, oferece outra pista valiosa sobre o sistema de informações jesuítico. Embora o teor desta carta se refira, em grande parte, aos fatos ocorridos em Pernambuco ela não faz parte dos códices do Brasil, como a princípio era de se esperar. Terá sido um erro cometido por algum obscuro e desconhecido jesuíta do Archivum Romanum Societatis Iesu? Não é a nossa opinião. Apesar dos assuntos que trata, e conforme determinam as Constituições, a carta foi encaminhada à sede dos inacianos em Roma pelos jesuítas da Província de Portugal. Portanto, o códice Lusitania 74, no qual foi encadernada esta carta do padre Francisco Ferreira, ajuda a elucidar essa questão. Ponto para os jesuítas!

No entanto, ainda persiste uma pergunta: qual seria o motivo que moveu o padre Francisco Ferreira a informar o Geral dos jesuítas sobre os efetivos das tropas holandesas em Pernambuco?

À primeira vista, pode parecer que as informações contidas na carta do jesuíta não eram relevantes para o padre Vitelleschi, mas, com toda a certeza, interessavam muito ao rei de Espanha e aos seus estrategistas. Portanto, a passagem dessa carta pela cidade de Lisboa, atendia inicialmente às especificidades da tramitação da correspondência jesuítica na Europa. Afinal, a rota que ligava Antuérpia-Lisboa-Roma já era utilizada há algum tempo, pelos religiosos da Missio Hollandica.

Ao chegar a Portugal, aquela carta do padre Francisco Ferreira foi prontamente entregue ao provincial dos jesuítas. Este certamente levou em conta a relevância das informações estratégicas enviadas pelo padre Ferreira. Por essa razão, é possível que o superior dos inacianos portugueses, tenha se encarregado de fazer com que tais notícias fossem enviadas a Madri e chegassem aos ouvidos de Filipe III. 
Como se pode perceber, o sistema de informações jesuítico contou com a participação dos religiosos de outras províncias da Companhia de Jesus, muitos dos quais não se envolveram diretamente na guerra que se travava no além mar. Portanto, os jesuítas sempre estiveram inseridos no esforço comum, que congregava todos os seus integrantes na luta contra as hostes de hereges calvinistas, cujas tropas representavam um perigo constante para as possessões coloniais do rei espanhol.

Apesar das dificuldades, dos riscos e das distâncias que certamente envolveram toda aquela operação realizada pelo padre Francisco Ferreira, que incluiu não apenas a coleta, mas o registro e o envio de informações, sua carta foi recebida em Portugal alguns meses antes que os canhões dos navios de Maurício de Nassau disparassem os primeiros tiros contra a cidade de Salvador.

Levando-se em conta os meios da época, também merece ser destacada a rapidez com que os informes colhidos pelo padre Francisco Ferreira foram difundidos pelo sistema de informações jesuítico. Desse modo, as notícias que davam conta de que uma nova incursão da WIC ao Brasil estava em preparação, chegaram ao conhecimento do rei de Espanha e de seus conselheiros e estrategistas, servindo, pelo menos, para corroborar as informações anteriores obtidas pelos agentes espanhóis.

Nesse sentido, cabe ressaltar que as ordens para que se organizasse a Armada que partiria para 'Restaurar Pernambuco', como então se dizia em Madri e Lisboa, foram emitidas com quase dois anos de antecedência. A adoção dessas medidas indica claramente que o rei de Espanha possuía informações confiáveis sobre os planos de ataque dos holandeses à sede do governo colonial na Bahia. Por conseguinte, a preparação da Armada, cujo comando caberia ao Conde da Torre, foi iniciada bem antes do cerco àquela cidade pelas tropas comandadas por Mauricio de Nassau, e não em razão da derrota que o governador do Brasil holandês sofreu em maio de 1638, conforme afirmaram alguns cronistas.

Quanto ao padre Francisco Ferreira, graças aos catálogos jesuíticos, sabe-se que sua libertação dos cárceres da WIC ocorreu em troca de alguns holandeses aprisionados em Portugal. De todo modo, é certo que o missionário deixou a cidade de Antuérpia nos últimos meses de 1636. Ao que parece tencionava chegar a Portugal e dali retornar ao Brasil. Todavia, jamais cumpriu o seu intento. Padre Ferreira já estava em território espanhol nos primeiros meses de 1637. E, durante sua estadia no Colégio 
da Companhia de Jesus em Santander, na Cantábria, morreu em consequência dos achaques que contraíra durante sua permanência nas prisões das Províncias Unidas.

Morte de um combatente da Igreja romana, como tantos outros que defenderam os aldeamentos do Brasil em face dos holandeses, malgré Manoel de Moraes. Tudo isto documentado pelos inacianos e depositado no arquivo jesuítico no Vaticano. Arquivo precioso de fontes históricas, vale repetir. Organização arquivística típica de uma ordem religiosa que atuava, vale sugerir, como um setor de inteligência da Igreja de Roma. Em um tempo em que as escolhas religiosas eram elemento inseparável das identidades pessoais, coletivas e políticas. 
Fênix - Revista de História e Estudos Culturais

Janeiro - Junho de 2019 Vol.16 Ano XVI no 1

ISSN: $1807-6971$

DOI: $10.35355 / 000008$

Disponível em: www.revistafenix.pro.br 